\title{
Concentration, Temperature and Storage duration Influence Chemical Stability of Compost Tea
}

\author{
Sanjamveer S. Vehniwal ${ }^{1}$, Raphael Ofoe ${ }^{1} \&$ Lord Abbey $^{1}$ \\ ${ }^{1}$ Department of Plant, Food, and Environmental Sciences, Dalhousie University, Faculty of Agriculture, 50 \\ Pictou Road, P.O. Box 550, Truro B2N 5E3, Nova Scotia, Canada \\ Corresponding: Lord Abbey, Faculty of Agriculture, 50 Pictou Road, P.O. Box 550, Truro B2N 5E3, Nova Scotia, \\ Canada. Tel: 1-902-893-6683. E-mail: loab07@ gmail.com
}

Received: April 17, 2020 Accepted: June 9, 2020 Online Published: June 17, 2020

doi:10.5539/sar.v9n3p87 URL: https://doi.org/10.5539/sar.v9n3p87

\begin{abstract}
Chemical stability is one of the key quality control criterion for complex degradable materials with an active microbial community like compost tea, but largely understudied. A laboratory study was performed to assess the chemical stability of varying concentrations $(0,2.5,5,10,15,20,30,50$ and $100 \%)$ of municipal solid waste (MSW) compost tea stored at different temperatures $\left(4^{\circ}, 10^{\circ}, 22^{\circ}\right.$ and $\left.35^{\circ} \mathrm{C}\right)$ and storage time $(0,13,2639$ and 52 days). A 2-dimension principal component biplot confirmed close relationship amongst total dissolved solids (TDS), electric conductivity (EC) and salinity while $\mathrm{pH}$ was less related and turbidity was isolated. TDS in the MSW compost tea did not change at a storage temperature of $4^{\circ} \mathrm{C}$ or $10^{\circ} \mathrm{C}$ but was significantly $(\mathrm{P}<0.05)$ increased by $4.3 \%$ when the storage temperature was raised to $35^{\circ} \mathrm{C}$. Also, TDS increased sharply from 93.25 $\mathrm{mg} / \mathrm{L}$ on day 1 to $111.31 \mathrm{mg} / \mathrm{L}$ on day 26 after which it remained unchanged. EC increased by approximately $8 \%$ only when the MSW compost tea was stored at $35^{\circ} \mathrm{C}$. The EC on the other hand increased by $19.4 \%$ from 131.28 $\mu \mathrm{S} / \mathrm{cm}$ on day 1 when it peaked on day 26 and plateaued off to day 52 . The change in $\mathrm{pH}$ was small and ranged from 7.44 to 7.67. Concentration had the strongest association with TDS, EC, salinity and turbidity and did not vary with storage time nor temperature. A multilinear regression $(\mathrm{Y}=\alpha \mathrm{D}+\beta \mathrm{C}+\gamma \mathrm{T}+\mathrm{k})$ showed significant $(\mathrm{P}<0.05)$ coefficients for all the independent variables except the coefficients for temperature in the turbidity, salinity and $\mathrm{pH}$ regression models. In conclusion, the chemical stability of the MSW compost tea was dependent on the storage temperature and storage duration. Chemical stability was reached after 26 days of storage while cold storage at $4^{\circ} \mathrm{C}$ or $10^{\circ} \mathrm{C}$ reduced chemical alteration.
\end{abstract}

Keywords: organic amendment, compost storage, chemical stability, shelf-life, municipal solid waste

\section{Introduction}

Composting is a global strategy for organic waste management. The resultant mature and stable compost is rich in beneficial microbiome, humic substances such as humic acids, fulvic acids and humins, and non-humic substances such as micro- and macro-nutrients, plant growth regulators and various macromolecules (Bhat et al., 2018; Xu et al., 2018). These qualities confer the popularity and the many benefits of compost for agricultural and environmental applications such as soil quality enhancement, bioremediation and soil erosion control. Mature and finished compost can be used as it is or extracted for specific uses such as foliar, drench and hydroponic applications. One such extracted material is water-based extracts of compost commonly referred to as compost tea, which has recently gained prominence in both organic and conventional agriculture. This has led to commercial production of different formulations of compost teas and exploitation of its use in agriculture. For instance, Yu et al. (2019) increased the efficacy of compost tea using microwave irradiation at $400 \mathrm{~W}$ for 10 mins. The efficacies of different formulations of compost teas are well acknowledged and documented. However, it can be argued that the stability of their physical, chemical and microbiological properties are critical to their various applications and functions but largely understudied.

Reports showed that compost tea suppressed plant diseases such as fusarium (Fusarium solani) on potatoes (Solanum tuberosum; Samet et al., 2018); and powdery mildew (Sphaerotheca pannosa) on rose (Rosa spp.; Seddigh \& Kian, 2018). Enhancement of compost tea with specific additives like molasses, fish hydrolysate, rock dust, soluble kelp and humic acids are developed to target specific groups of beneficial microorganisms to enhance their proliferation and functions for disease suppression and nutrients mineralization. Additionally, the 
water extraction process makes soluble mineral nutrients, organic acids, plant growth regulators and biochemical compounds more available in compost tea (Pant et al., 2012). Another important index is the concentration of hydrogen ion potential $(\mathrm{pH})$, which is an important factor regulating the solubility and availability of nutrients in media. The acceptable range for optimum microbial activities is between pH 6.0 - 7.5 (Majlessi et al., 2012; Islam et al., 2016). The totality of these water-soluble compounds can be indiscriminately estimated by measuring the electric conductivity, total soluble solids, salinity and pH (Martinez-Suller et al., 2010; Abbey et al., 2013). These chemical indices may vary with the concentration and formulation of the compost tea, the storage temperature and storage duration. However, information on these influential factors and their relationship with compost tea chemical indices are limited.

The study by Brohon et al. (1999) demonstrated that soil microbial biomass was progressively reduced when storage temperature was raised from $4^{\circ} \mathrm{C}$ to $37^{\circ} \mathrm{C}$. Furthermore, Ingham \& Alms (2003) reported that the storage of compost at $50 \%$ moisture content and high temperature of approximately $65^{\circ} \mathrm{C}$ killed microorganisms present in compost. These observations suggested that the chemical and microbiological stability of compost tea can be altered with variations in storage temperature and duration. As such, we postulated that the chemical stability of MSW compost tea will be reduced at temperatures above room conditions (i.e. $>22^{\circ} \mathrm{C}$ ) and prolonged storage. Therefore, this present study aimed to determine the chemical stability of varying concentrations of MSW compost tea stored at different temperatures and storage time.

\section{Materials and Methods}

\subsection{Experiment Site}

The study was performed at the Biostimulant and Compost Laboratory, Department of Plant, Food, and Environmental Sciences, Faculty of Agriculture, Dalhousie University. Municipal solid waste compost was supplied by Fundy Compost Inc., Brookfield, NS, Canada.

\subsection{Preparation of Compost Tea}

The MSW compost at 35\% moisture content was sieved using a 2-mm screen size. The compost tea stock solution was prepared by adding $100 \mathrm{~g}$ of the sieved compost to $2 \mathrm{~L}$ of deionized water in an Erlenmeyer flask. The top of the flask was covered with parafilm and a small hole of about 1-mm diameter was made at the top to allow aeration. The mixture was stirred for $24 \mathrm{hr}$ at $1100 \mathrm{rpm}$ using a hot plate isotemperature magnetic stirrer (Fisher Scientific, Toronto, ON, Canada) under room temperature and relative humidity conditions. The stirred mixture stood for $24 \mathrm{hr}$ to settle before filtering using a NALGENE rapid flow filter with disposable bottle top filters lined with a polyethersulfone membrane (Fisher Scientific, Toronto, ON, Canada). Compost tea concentrations of $0,2.5,5,10,15,20,30,50$ and $100 \%(\mathrm{v} / \mathrm{v})$ were prepared from the stock solution using deionized water.

\subsection{Nutrient Analysis of MSW Compost and Compost Tea}

Duplicate samples of $300 \mathrm{~g}$ of the MSW compost and $500 \mathrm{~mL}$ of the compost tea stock solution were sent to the Nova Scotia Department of Agriculture (NSDA) Laboratory Services, Truro, NS for nutrients analysis. Total nitrogen $(\mathrm{N})$ was determined by the AOAC-990.03 combustion method (AOAC, 2003a) using a LECO-Spec Analyzer (TruSpec ${ }^{\circ}$ Micro, LECO, MI). The remaining nutrients elements were determined using the AOAC-968.08 inductively coupled plasma (ICP) spectrometer method (AOAC, 2003b).

\subsection{Compost Tea Storage}

The individual MSW compost tea concentrations were stored in a 1-L closed glass bottles at four different storage temperatures i.e. $4^{\circ}, 10^{\circ}, 22^{\circ}$ and $35^{\circ} \mathrm{C}$. The $4^{\circ} \mathrm{C}$ storage was a walk-in cooler (Barr Refrigeration, Oshkosh, USA); the $10^{\circ} \mathrm{C}$ and the $35^{\circ} \mathrm{C}$ storage were growth chambers (model LHT-2103D, Z-Sciences Crop, Quebec, Canada); and room temperature condition in the laboratory at $22^{\circ} \mathrm{C}$. The total storage time was 52 days from June to August.

\subsection{Data Collection}

The experimental design was a completely randomized 3 -factor design with three sample replications. Triplicate samples of the individual MSW compost tea treatments were collected for analysis every $13^{\text {th }}$-day for 52 days. These data were potential hydrogen ion concentration $(\mathrm{pH})$, electric conductivity $(\mathrm{EC})$, salinity and total dissolved solids (TDS) using PCS Testr 35 multimeter (model 35425-10; Oakton, Vernon Hills, USA). Turbidity was determined using a turbidity meter (model T-100; Oakton Vernon Hills, USA). Both the PCS Testr 35 multimeter and the turbidity meter were calibrated with certified accurate calibration standards before use. 


\subsection{Statistical Analyses}

The effects of compost tea concentration, storage duration (days) and storage temperature $\left({ }^{\circ} \mathrm{C}\right.$ ) and their interactions on the chemical indices were examined using a three-way factorial analysis of variance. The analysis was performed using a General Linear Model procedure in SAS version 9.4 (SAS Institute Inc., North Carolina, USA). For more statistical power, repeated measures analysis was performed to control for factors that cause variability between the treatments. A biplot of principal component analysis was performed to determine the association between the independent and dependent treatments using XLSTAT version 19.1 (Addinsoft, New York, USA). The data were further explored using descriptive statistics. These were the maximum value, minimum value, mean value, standard error of the mean and standard deviation to check the validity of the data for developing multiple linear regression models using SAS. The multiple linear regression model was $\mathrm{Y}=\alpha \mathrm{D}+\beta \mathrm{C}$ $+\gamma \mathrm{T}+\mathrm{k}$; where $\mathrm{k}=$ intercept, $\mathrm{D}=$ storage time, $\mathrm{C}=\mathrm{MSW}$ compost tea concentration and $\mathrm{T}=$ storage temperature; $\alpha, \beta$ and $\gamma$ are the coefficients for storage time, MSW compost concentration and storage temperature, respectively. Correlations amongst EC, pH, TDS, salinity and turbidity were evaluated using Pearson correlation coefficients in Minitab version 18.3 (Minitab, Inc., State College, Pennsylvania, USA). All tests were declared significant at $\mathrm{P} \leq 0.05$.

\section{Results and Discussion}

Mineral nutrients composition of the municipal solid waste (MSW) compost (Table SA1) used for the present study falls within the range reported for other compost from similar sources supplied by the manufacturer and reported in Abbey et al. (2018). The carbon-nitrogen (C:N) ratio of 1.72 and the concentration of the individual nutrients suggested a nutrient-dense, mature and stable MSW compost. In Canada and most jurisdictions, irrigation water quality test includes analysis of human disease pathogens such as Escherichia coli, fecal coliform and Salmonella spp. (Steele \& Odumeru, 2004). Escherichia coli and fecal coliform are used to assess bacteria counts from non-faecal and faecal origins while Salmonella spp. determination is used to assess contamination in waste water. The concentrations of these pathogens in the MSW compost used for the study (Table SA1) were found to be below the hazardous level for general irrigation i.e. $<1000 \mathrm{MPN} / 100 \mathrm{~mL}$ for faecal coliform and E. coli. The prepared MSW compost tea stock solution had a pH of 7.4 similar to the solid phase $\mathrm{pH}$ of 7.7. Compost contains nutrients and salts, and the amount of salts and nutrient ions in the liquid phase are in equilibrium with those in the solid phase (Carmo et al., 2016). We found that the nutrient composition of the MSW compost tea stock solution was lower than that of the solid phase due to dilution effect as expected (Table SA2).

The main effects of the MSW compost tea concentration, storage temperature and storage time on total dissolved solids (TDS), turbidity, electric conductivity (EC), salinity and $\mathrm{pH}$ were significant $(\mathrm{P}<0.05)$ with two exceptions (Table 1). That is, non-significant effects were observed for firstly, the MSW compost tea concentration on $\mathrm{pH}$ ( $\mathrm{P}$ $=0.17)$; and secondly, the storage time effect on salinity $(\mathrm{P}=0.31)$. None of the 2- or 3-way interaction effects were significant $(\mathrm{P}>0.05)$ apart from the significant $(\mathrm{P}=0.03)$ TDS response to the MSW compost tea concentration*storage temperature*storage time interaction.

Table 1. Significance of P-values $(\alpha=0.05)$ from analysis of variance of municipal solid waste compost tea chemical indices as influenced by concentration, storage temperature and storage time

\begin{tabular}{lllllll}
\hline Source of variation & df & pH & EC & TDS & Turbidity & Salinity \\
\hline Concentration & 8 & 0.17 & $<0.0001$ & $<0.0001$ & $<0.0001$ & $<0.0001$ \\
Storage time & 4 & 0.02 & 0.01 & 0.009 & $<0.0001$ & 0.008 \\
Storage temperature & 3 & 0.04 & 0.01 & 0.003 & 0.0004 & 0.31 \\
Conc*SD & 32 & 0.11 & 0.86 & 0.36 & 0.19 & 0.082 \\
Conc*T & 24 & 0.13 & 0.89 & 0.16 & 0.87 & 0.1038 \\
SD*T & 12 & 0.08 & 0.49 & 0.89 & 0.73 & 0.519 \\
Conc*SD*T & 96 & 0.19 & 0.77 & 0.03 & 0.91 & 0.41 \\
\hline
\end{tabular}

df, degree of freedom; $\mathrm{pH}$, hydrogen ion concentration; EC, electric conductivity; TDS, total dissolved solids; Conc, municipal solid waste compost tea concentration; SD, storage time; T, storage temperature.

Pearson correlation coefficients also showed that EC, TDS and salinity had strong and positive association $(\mathrm{r}=$ 0.97, $\mathrm{P}<0.05$ ) with the MSW compost tea concentration (Table 2; Fig. SA1). MSW compost tea concentration association with turbidity was moderate $(\mathrm{r}=0.63)$ but weak $(\mathrm{r}=0.24)$ with $\mathrm{pH}$ although they were all significant $(\mathrm{P}<0.05)$. Also, the associations between EC, TDS, turbidity and salinity versus storage time were weak but 
significant $(\mathrm{P}<0.05)$ except non-significant $(\mathrm{P}>0.05)$ association with $\mathrm{pH}(\mathrm{r}=0.08)$. Amongst the MSW compost tea chemical indices, all the associations were positively significant $(\mathrm{P}<0.05)$. The association was strong $(\mathrm{r}=$ $0.999)$ amongst TDS, EC and salinity, but moderate $(\mathrm{r}=0.537)$ for turbidity and weak $(\mathrm{r}=0.215)$ for $\mathrm{pH}$ versus TDS, EC or salinity (Table 2; Fig. SA1). The negative association between variables suggested changes in opposite directions whereas positive association suggested changes in the same direction. Moreover, turbidity increased with an increase in MSW compost tea concentration (i.e. positive association) while turbidity was reduced as time progresses (i.e. negative association) (Table 2). To further elaborate these relationships, a two-dimension (2-D) principal component analysis (PCA) biplot was used to assess the association amongst the different variables (Fig.1). The 2-D PCA biplot showed projections of the variables in the factors space (i.e. F1 and F2). The biplot explained approximately $72 \%$ of the variations in the dataset. The PCA biplot suggested that the isolated turbidity was unique as compared to the response variables TDS, EC and salinity which are chemically related. The concentration of the MSW compost tea had a significantly $(\mathrm{P}<0.05)$ strong correlation with all the response variables but weak for $\mathrm{pH}$. However, the other factors (i.e. temperature and storage time) had no correlation with the response variables but storage time, which was negatively correlated with turbidity.

Table 2. Pearson's correlation coefficients for explanatory and response variables of municipal solid waste compost tea as influenced by concentration, storage temperature and storage time

\begin{tabular}{llllllll}
\hline Variable & Conc & T & SD & EC & TDS & Salinity & Turbidity \\
\hline T & 0.000 & & & & & & \\
SD & 0.000 & 0.000 & & & & & \\
EC & $\mathbf{0 . 9 7 3} * * *$ & 0.039 & 0.090 & & & & \\
TDS & $\mathbf{0 . 9 7 4}^{* * *}$ & 0.040 & $\mathbf{0 . 0 9 0} *$ & $\mathbf{0 . 9 9 9 * * *}$ & & & \\
Salinity & $\mathbf{0 . 9 7 2}^{* * *}$ & 0.050 & $\mathbf{0 . 0 8 7} *$ & $\mathbf{0 . 9 9 9}^{* * *}$ & $\mathbf{0 . 9 9 9}^{* * *}$ & & \\
Turbidity & $\mathbf{0 . 6 2 8}^{*}$ & -0.011 & $\mathbf{- 0 . 4 6 4}$ & $\mathbf{0 . 5 3 7}^{*}$ & $\mathbf{0 . 5 3 8}^{*}$ & $\mathbf{0 . 5 3 7}^{*}$ & \\
pH & $\mathbf{0 . 2 3 6}^{*}$ & -0.021 & 0.076 & $\mathbf{0 . 2 1 5} *$ & $\mathbf{0 . 2 1 6}^{*}$ & $\mathbf{0 . 2 1 6}^{*}$ & $\mathbf{0 . 2 6 4}^{*}$ \\
\hline
\end{tabular}

Conc, municipal solid waste compost tea concentration; T, storage temperature; SD, storage time; EC, electric conductivity; TDS, total dissolved solids; $\mathrm{pH}$, hydrogen ion concentration.

Values in bold are different from 0 with a significance level $\alpha=0.05$ where $* * *, * *, *$ are significant at $\mathrm{P}<0.001$, $\mathrm{P}<0.01$ and $\mathrm{P}<0.05$, respectively.

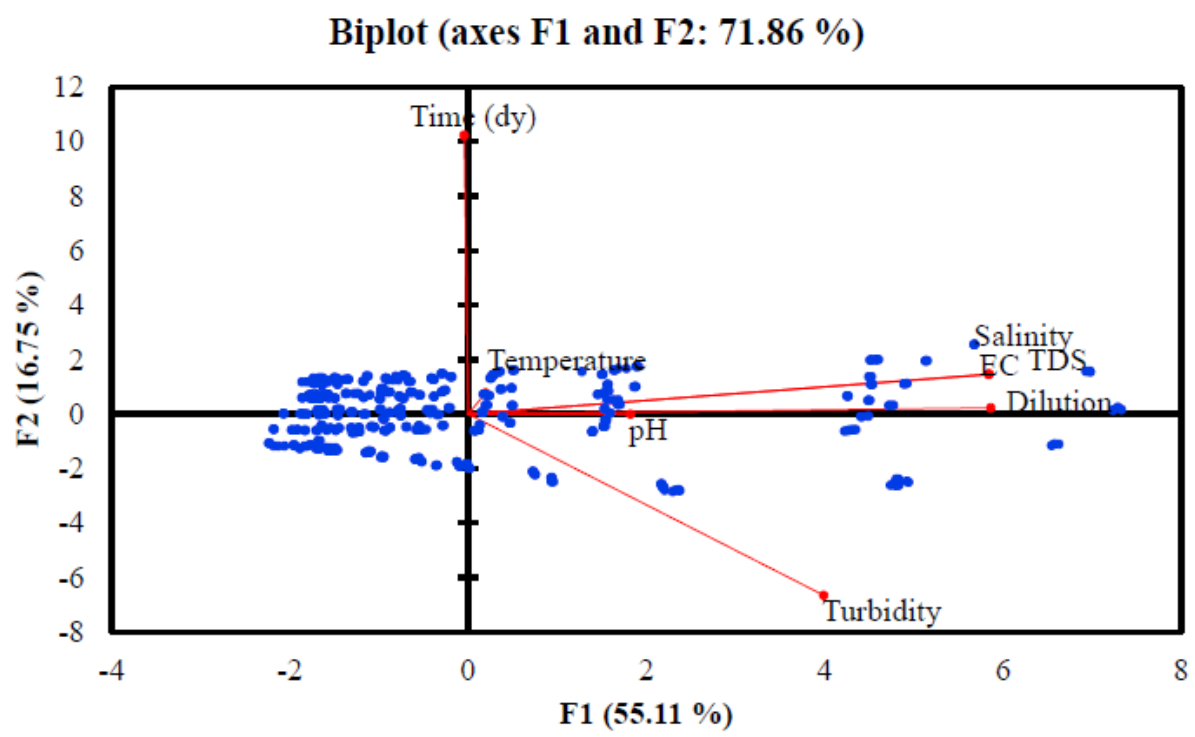

- Active variables - Active observations

Figure 1. A two-dimensional principal component analysis biplot showing relationships amongst the explanatory variables municipal solid waste compost concentration (dilution), storage temperature and storage time and the response variables total dissolved solids (TDS), electric conductivity (EC), salinity, potential hydrogen ion concentration $(\mathrm{pH})$ and turbidity 
Variations in TDS for the different MSW compost tea concentrations were highly significant $(\mathrm{P}=0.0001)$. As the concentration of the MSW compost tea was increased from $0 \%$ (blank) to $100 \%$ (stock), TDS increased linearly from $38 \mathrm{mg} / \mathrm{L}$ to approximately $300 \mathrm{mg} / \mathrm{L}$ (Fig. 2A). The source of TDS is decomposed organic matter, humic and non-humic substances in the solid phase compost. The concentrations of water-soluble components of these substances determined the TDS values as well as values for turbidity, EC, salinity and $\mathrm{pH}$ as reported by Carmo et al. (2016). As such, it was expected that an increase in the concentration of the MSW compost tea will increase TDS. However, TDS did not significantly $(\mathrm{P}>0.05)$ change when the MSW compost tea was stored at $4^{\circ} \mathrm{C}$ or $10^{\circ} \mathrm{C}$ but gradually increased by $2 \%$ when the storage temperature was increased to $22^{\circ} \mathrm{C}$ and by $4.2 \%$ at $35^{\circ} \mathrm{C}$ (Fig. 2B). A highly significant $(\mathrm{P}=0.0001)$ increase of $19.4 \%$ in TDS was recorded on day 26 , which remained constant up to day 56 (Fig. 2C). Thus, while different MSW concentrations of the compost tea will have different TDS values, higher storage temperature (i.e. $>10^{\circ} \mathrm{C}$ ) and storage time (i.e. up to 20 days) increased the dissolution of water-soluble substances in the deionized water used for the preparation of the MSW compost tea. Microbial and enzymatic activities might have been favored in storage which might have also contributed to the increased dissolution of water-soluble materials leading to increased EC, TDS and salinity. Further study is required to examine this effect.

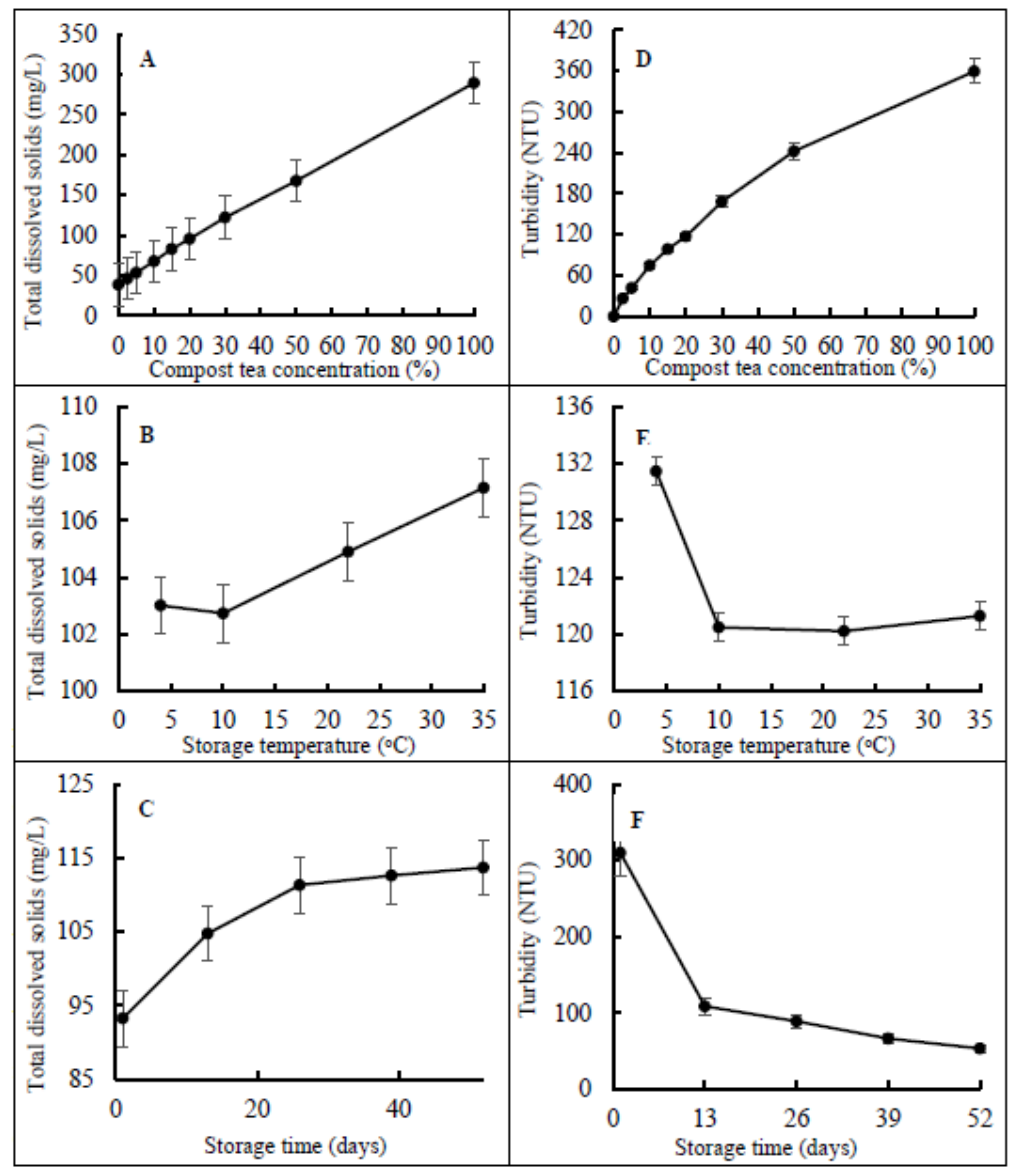

Figure 2. Total dissolved solids and turbidity of municipal solid waste compost tea as affected by different concentrations, storage time and storage duration

The pattern of the TDS in Figure 2A-C can be explained by the pattern of MSW compost tea turbidity in Figure 2D-F. An increase in the concentration of the MSW compost tea means high amount of particulate matter and increased turbidity. It was evident that as the concentration of the MSW compost tea increased from 0 to $100 \%$, turbidity increased in a consistent curvilinear fashion from negligible (control, deionized water alone) to 359.31 NTU (Fig. 2D). In storage, turbidity was highest at $4^{\circ} \mathrm{C}$ (i.e. $131.44 \mathrm{NTU}$ ) but declined steeply at storage temperatures $\geq 10^{\circ} \mathrm{C}$ (i.e. $120.49 \mathrm{NTU}$; Fig. 2E). There was also a rapid decline in turbidity from $309.77 \mathrm{NTU}$ after day 1 of storage to $53.46 \mathrm{NTU}$ on day 52 (Fig. 2F). It can be surmised that suspended particles coalesced and precipitated at storage temperatures higher than $4^{\circ} \mathrm{C}$ to cause more than $8.3 \%$ reduction in turbidity. Furthermore, extended storage time allowed for relatively larger particles to settle and thereby, reduce turbidity 
by approximately $65 \%$ at day 13 and $83 \%$ at day 52 . However, a decline in turbidity only moderately reduced TDS as suggested by the correlation analysis (Table 2). This observation confirmed that the composition of the TDS was more than just dissolved particulate matter in the MSW compost tea that later settled in the solution.

The EC value of the MSW compost tea increased linearly at a rate of $2.43 \mu \mathrm{S} / \mathrm{cm}$ per unit increase in percentage concentration (Fig. 3A). Generally, EC is used to estimate the concentration of ionic substances in solutions including compost tea (Martinez-Suller et al., 2010; Abbey et al., 2013). According to Islam et al. (2016), EC values increase with an increase in compost:water ratio from 1:10 to 1:2.5. In the present study, the ionic substances in the MSW compost tea will include various nutrients, salts and ionized macromolecules which were expected to increase with an increase in the concentration of the MSW compost tea and higher EC value. EC did not significantly $(\mathrm{P}>0.05)$ change when the MSW compost tea was stored at $4^{\circ}, 10^{\circ}$ and $22^{\circ} \mathrm{C}$ but rose by approximately $8 \%$ at $35^{\circ} \mathrm{C}$ (Fig. 3B). There is a linear relationship between $\mathrm{EC}$ and temperature and viscosity of water (Hayashi, 2004), which explains the present finding. An increase in storage temperature could cause a decrease in viscosity and increase the concentrations and mobility of ions in solution due to dissociation of molecules (Islam et al., 2016). We found that EC increased from $130 \mu \mathrm{S} / \mathrm{cm}$ on day 1 to $160 \mu \mathrm{S} / \mathrm{cm}$ on day 39 of storage, and remained constant up to day 52 when the experiment was terminated. Similar results have also been reported by Kim et al. (2015). In conformity with previous studies by Abbey et al. (2013), we found a strong linear relationship between TDS, EC and salinity (Table 2). Consequently, the patterns of change in the MSW compost tea salinity at the varied concentrations, storage temperature and storage time (Figs 3D-F) were similar to those found for TDS (Figs 2A-C) and EC (Figs 3A-C).

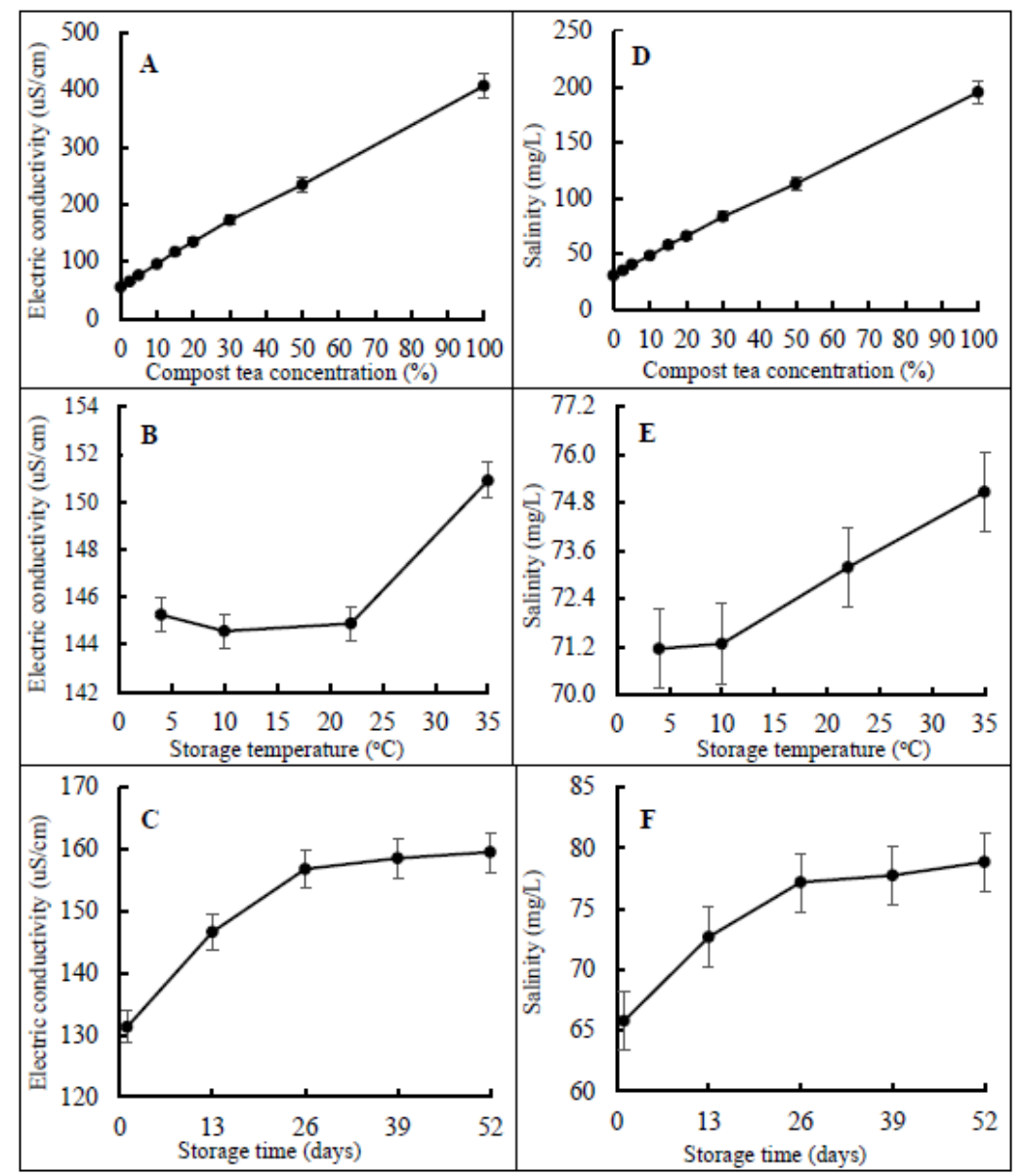

Figure 3. Electric conductivity and salinity of municipal solid waste compost tea as affected by different concentrations, storage time and storage duration

The only difference was that while EC was not altered when the MSW compost tea was stored at $4^{\circ} \mathrm{C}, 10^{\circ} \mathrm{C}$ or $22^{\circ} \mathrm{C}$ but increased by $4.4 \%$ at $35^{\circ} \mathrm{C}$ (Figs 3B). Also, TDS and salinity were increased by $2.1 \%$ and $2.6 \%$ at $22^{\circ} \mathrm{C}$ or $4.3 \%$ and $5.4 \%$ at $35^{\circ} \mathrm{C}$, respectively (Fig $2 \mathrm{~B}$; Fig $3 \mathrm{E}$ ). Both $\mathrm{EC}$ and salinity reached a peak with a respective 
increase of $19.4 \%$ and $17.3 \%$ from day 1 before plateauing off after day 26 .

The $\mathrm{pH}$ of the MSW compost tea was significantly $(\mathrm{P}<0.05)$ influenced by storage temperature $(\mathrm{P}=0.04$; Fig. $4 \mathrm{~A})$ and storage time $(\mathrm{P}=0.02$; Fig. $4 \mathrm{~B})$, but not concentration $(\mathrm{P}>0.05)$ as confirmed by the ANOVA in Table 1 (data not presented). The change in $\mathrm{pH}$ was small and ranged from 7.44 to 7.67. The $\mathrm{pH}$ of the MSW compost tea was moderately reduced when stored at $10^{\circ} \mathrm{C}$ but re-gained the $\mathrm{pH}$ when the storage temperature was raised above $10^{\circ} \mathrm{C}$ ( Fig. $4 \mathrm{~A}$ ). These moderate changes can possibly, be attributed to the release of ammonia and other organic acids such as oxalic, citric and malic acids (Majlessi et al., 2012; Islam et al., 2016). The release of these compounds can be attributed to microbial degradation of organic compounds in the MSW compost tea over time and under the influence of storage temperature. Additionally, Majlessi et al. (2012) explained that $\mathrm{pH}$ change is a key factor that regulates the solubility and availability of nutrients in growing media and the acceptable $\mathrm{pH}$ range for microorganisms is 6.0 to 7.5. This suggested that the positive association between $\mathrm{pH}$ and EC, TDS and salinity although low (Table 2), can be ascribed to increased nutrients solubility in the MSW compost tea as a result of microbial activities. Further study is required to examine the microbial effect on these chemical properties in compost tea.

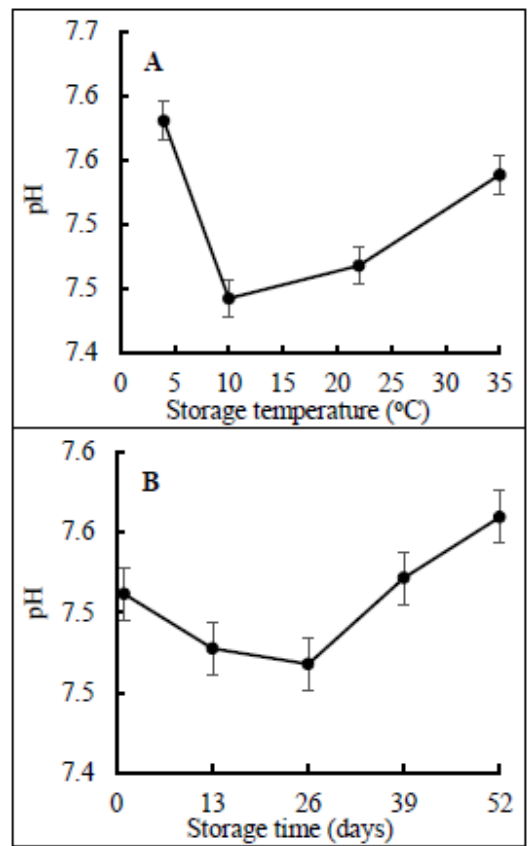

Figure 4. Hydrogen ion concentration $(\mathrm{pH})$ of municipal solid waste compost tea as affected by different storage time and storage duration

The explanatory variables of MSW compost concentration, storage temperature and storage time were used to predict the outcome of each of the response variables i.e. EC, turbidity, TDS, salinity and $\mathrm{pH}$ in a multilinear regression model (Table 3). The coefficients of intercepts for all the variables in each of the regression model was highly significant $(\mathrm{P}<0.05)$ but not for temperature in the turbidity, salinity and $\mathrm{pH}$ models.

Table 3. Multiple linear regression model $(\mathrm{Y}=\alpha \mathrm{D}+\beta \mathrm{C}+\gamma \mathrm{T}+\mathrm{k})$ indicating relationship of chemical indices as influenced by municipal solid waste compost tea concentration (C), storage time (D) and storage temperature (T)

\begin{tabular}{lllllllll}
\hline Response variable & Constant & \multicolumn{6}{l}{ Coefficients } & \\
\hline & $\mathbf{k}$ & $\mathbf{S E}$ & $\boldsymbol{\alpha}$ & $\mathbf{S E}$ & $\boldsymbol{\beta}$ & $\mathbf{S E}$ & $\boldsymbol{\gamma}$ & $\mathbf{S E}$ \\
\hline Electric conductivity & $41.19^{* *}$ & 2.39 & $0.52^{* *}$ & 0.05 & $3.49^{* *}$ & 0.03 & $0.03^{*}$ & 0.08 \\
Salinity & $26.32^{* *}$ & 4.6 & $0.23^{*}$ & 0.1 & $1.68^{* *}$ & 0.06 & 0.01 & 0.15 \\
Total dissolved solids & $31.23^{* *}$ & 2.04 & $0.33^{* *}$ & 0.04 & $2.44^{* *}$ & 0.02 & $0.20^{*}$ & 0.07 \\
Turbidity & $148.4^{* *}$ & 11.2 & $-4.25^{* *}$ & 0.24 & $3.52^{* *}$ & 0.15 & -0.19 & 0.38 \\
pH & $7.42^{* *}$ & 0.02 & 0.001 & 0.0005 & $0.002^{*}$ & 0.0003 & -0.003 & 0.00087 \\
\hline
\end{tabular}

$\alpha, \beta, \gamma, \mathrm{k}$, coefficients of storage time (D), municipal solid waste compost tea concentration (C), storage temperature $(\mathrm{T})$ and constant, respectively for the regression model; SE, standard error; *, ** indicates statistical significance at $\mathrm{P}<0.05$ and $\mathrm{P}<0.001$, respectively. 
The MSW compost tea concentration was the only variable with significant $(\mathrm{P}<0.05)$ coefficient for the $\mathrm{pH}$ model. It is important to note that the relevance and extent to which a variable contributed to the regression model was dependent on the significance of the P-value associated with the coefficients. Therefore, a non-significant coefficient with $\mathrm{P}>0.05$ can be eliminated from the multilinear regression model. A negative coefficient such as the coefficient for the storage time (i.e. -4.25) in the turbidity model means the explanatory variable to which the coefficient was affecting have a reducing effect on the response variable. For example, TDS $=0.33 \mathrm{D}+2.44 \mathrm{C}+0.2 \mathrm{~T}+31.23$ implied an increase in storage duration by 1 day will increase TDS by 0.33 $\mathrm{mg} / \mathrm{L}$ when the storage temperature (T) and MSW compost tea concentration (C) were kept constant. For $\mathrm{pH}$, the regression model will be $\mathrm{pH}=0.002 \mathrm{C}+7.42$ since all the other coefficients for $\mathrm{D}$ and $\mathrm{T}$ were not significant $(\mathrm{P}>0.05)$. Similarly, $\mathrm{EC}=0.52 \mathrm{D}+3.49 \mathrm{C}+0.03 \mathrm{~T}+41.19 ;$ Salinity $=0.23 \mathrm{D}+1.68 \mathrm{C}+26.32 ;$ and Turbidity $=$ $-4.25 \mathrm{D}+3.52 \mathrm{C}+148.4$. These regressions models can be used for future determination of specific chemical alterations in compost tea.

In conclusion, the chemical quality indices of MSW compost tea can be predicted by the concentration, storage temperature and storage time. It was found that the chemical stability of compost tea can change with changes in storage temperature and storage duration until it reaches a peak. The findings suggested that the chemical stability of the MSW compost tea was reached 26 days after storage and remained constant up to 52 days when the experiment was terminated. Cold storage at $4^{\circ} \mathrm{C}$ or $10^{\circ} \mathrm{C}$ reduced chemical alteration with low EC, TDS, salinity and $\mathrm{pH}$ values. Thus, MSW compost tea could be subjected to higher temperatures, which has the potential to increase microbial activities and the values of these chemical quality indices before use. However, storage at lower temperatures will be appropriate to slow down microbial activities and alteration in chemical composition if the compost tea will not be used immediately. Future investigation on active microbial composition and their activities is required to fully elucidate their effect on the chemical stability of compost tea.

\section{Funding}

This study was funded by Divert Nova Scotia (Award \#RRFB 16-01) of which the authors are most grateful.

\section{Data availability statement}

The data for the nutrient composition of the solid phase municipal solid waste compost and the compost tea stock solution, correlation matrix and data used to support the findings of this study are included within the supplementary information files. Other data are available from the corresponding author upon request.

\section{Acknowledgement}

The authors wish to thank Divert Nova Scotia, Truro, NS for the funding and Dr. Samuel Asiedu and Dr. Jeff Hoyle for their assistance on student committee.

\section{References}

Abbey, L., Annan, N., Asiedu, S. K., Oluwaseun, E. E., \& Iheshiulo, E. M-A. (2018). Amino acids, mineral nutrients and efficacy of vermicompost and seafood and municipal solid wastes composts. International Journal of Agronomy, 8, 1-6. https://doi.org/10.1155/2018/6419467

Abbey, L., Rao, S. A., Hodgins, L. N., \& Briet, F. (2013). Drying and rehydration of vermicasts do not affect nutrient bioavailability and seedling growth. American Journal of Plant Nutrition and Fertilizer Technology, 3(1), 12-21. https://doi.org/10.3923/ajpnft.2013.12.21

AOAC. (2003a). Protein (crude) in animal feed: combustion method, AOAC official method 990.03. Official methods of analysis. 17th ed. Association of Official Analytical Chemists, Gaithersburg, MD.

AOAC. (2003b). Metals and other elements in plants and pet foods: inductively coupled plasma spectroscopic method, AOAC official method 968.08. Official methods of analysis. 17th ed. Association of Official Analytical Chemists, Gaithersburg, MD.

Bhat, S. A., Singh, S., Singh, J., Kumar, S., \& Vig, A. P. (2018). Bioremediation and detoxification of industrial wastes by earthworms: vermicompost as powerful crop nutrient in sustainable agriculture. Bioresource Technology, 252, 172-179. https://doi.org/10.1016/j.biortech.2018.01.003

Brohon, B., Delolme, C., \& Gourdon, R. (1999). Qualification of soils through microbial activities measurements influence of the storage period on int-reductase, phosphatase and respiration. Chemosphere, 38(9), 1973-1984. https://doi.org/10.1016/S0045-6535(98)00410-X

do Carmo, D. L., Silva, C. A., de Lima, J. M., \& Pinheiro, G. L. (2016). Electrical conductivity and chemical composition of soil solution: comparison of solution samplers in tropical soils. Revista Brasileira de 
Ciencia do Solo, 40, 1-17. https://doi.org/10.1590/18069657rbcs20140795

Hayashi, M. (2004). Temperature-electrical conductivity relation of water for environmental monitoring and geophysical data inversion. Environmental Monitoring and Assessment, 96, 119-128. https://doi.org/10.1023/B:EMAS.0000031719.83065.68

Islam, M. K., Yaseen, T., Traversa, A., Kheder, M. B., Brunetti, G., \& Cocozza, C. (2016). Effects of the main extraction parameters on chemical and microbial characteristics of compost tea. Waste Management, 52, 62-68. https://doi.org/10.1016/j.wasman.2016.03.042

Kim, M. J., Shim, C. K., Kim, Y. K., Hong, S. J., Park, J. H., Han, E. J., Kim, J. H., \& Kim, S. C. (2015). Effect of aerated compost tea on the growth promotion of lettuce, soybean, and sweet corn in organic cultivation. The Plant Pathology Journal, 31(3), 259-268. https://doi.org/10.5423/PPJ.OA.02.2015.0024

Majlessi, M., Eslami, A., Saleh, H. N., Mirshafieean, S., \& Babaii, S. (2012). Vermicomposting of food waste: assessing the stability and maturity. Iranian Journal of Environmental Health Science and Engineering, 9(1), 25. https://doi.org/10.1186/1735-2746-9-25

Martinez-Suller, L., Provolo, G., Brennan, D., Howlin, T., Carton, O. T., Lalor, S. T. J., \& Richards, K. G. (2010). A note on the estimation of nutrient value of cattle slurry using easily determined physical and chemical parameters. Irish Journal of Agriculture and Food Research, 49, 93-97. Retrieved from http://hdl.handle.net/11019/171

Pant, A. P., Radovich, T. J., Hue, N. V., \& Paull, R. E. (2012). Biochemical properties of compost tea associated with compost quality and effects on pak choi growth. Scientia Horticulturae, 148, 138-146. https://doi.org/10.1016/j.scienta.2012.09.019

Samet, M., Charfeddine, M., Kamoun, L., Nouri-Ellouze, O., \& Gargouri-Bouzid, R. (2018). Effect of compost tea containing phosphogypsum on potato plant growth and protection against Fusarium solani infection. Environmental Science and Pollution Research, 25(19), 18921-18937. https://doi.org/10.1007/s11356-018-1960-z

Seddigh, S., \& Kiani, L. (2018). Evaluation of different types of compost tea to control rose powdery mildew (Sphaerotheca pannosa var. rosae). International Journal of Pest Management, 64(2), 178-184. https://doi.org/10.1080/09670874.2017.1361050

Steele, M., \& Odumeru, J. (2004). Irrigation water as source of foodborne pathogens on fruit and vegetables. Journal of Food Protection, 67(12), 2839-2849. https://doi.org/10.4315/0362-028X-67.12.2839

Xu, P., Lai, C., Zeng, G., Huang, D., Chen, M., Song, B., Peng, X., Wan, J., Hu, L., Duan, A., \& Tang, W. (2018). Enhanced bioremediation of 4-nonylphenol and cadmium co-contaminated sediment by composting with Phanerochaete chrysosporium inocula. Bioresource Technology, 250, 625-634. https://doi.org/10.1016/j.biortech.2017.11.069

Yu, H., Iheshiulo, M-A. E., Gunupuru, L., \& Abbey, L. (2019). Microwave power level and exposure time alteration of compost tea efficacy, and growth of Plectranthus amboinicus. Horticulure International Journal, 3(4), 179-184. https://doi.org/10.15406/hij.2019.03.00127

\section{Appendix A}

Table SA1. Chemical composition of solid phase municipal solid waste compost used for the preparation of the compost tea stock solution

\begin{tabular}{lll}
\hline Compost Parameters & Unit & Value \\
\hline $\mathrm{pH}$ & & 7.7 \\
Cation Exchange Capacity & $\mathrm{meq} / 100 \mathrm{~g}$ & 48.6 \\
Organic matter & $\%$ & 25.21 \\
Total nitrogen & $\%$ & 1.72 \\
C:N ratio & & $9: 1$ \\
Escherichia coli & $\mathrm{MPN} / \mathrm{g}$ dry & 6 \\
Fecal Coliform & $\mathrm{MPN} / \mathrm{g}$ dry & 6 \\
Salmonella spp. & $\mathrm{P}-\mathrm{A} / 25 \mathrm{~g}(\mathrm{~mL})$ & Negative \\
Total Ar & $\mathrm{mgkg}^{-1}$ & 7.14 \\
Total Co & $\mathrm{mgkg}^{-1}$ & 7.10 \\
Total Cr & $\mathrm{mgkg}^{-1}$ & 17.75 \\
\hline
\end{tabular}




\begin{tabular}{lll}
\hline Total $\mathrm{Cu}$ & $\mathrm{mgkg}^{-1}$ & 50.50 \\
Total $\mathrm{Hg}$ & $\mathrm{mgkg}^{-1}$ & 0.11 \\
Total $\mathrm{Mo}$ & $\mathrm{mgkg}^{-1}$ & 1.3 \\
Total $\mathrm{Ni}$ & $\mathrm{mgkg}^{-1}$ & 14.77 \\
Total Pb & $\mathrm{mgkg}^{-1}$ & 24.25 \\
Total P & $\mathrm{mgkg}^{-1}$ & 681 \\
Total K & $\mathrm{mgkg}^{-1}$ & 2252 \\
Total $\mathrm{Mg}$ & $\mathrm{mgkg}^{-1}$ & 839 \\
Total Ca & $\mathrm{mgkg}^{-1}$ & 6676 \\
Total S & $\mathrm{mgkg}^{-1}$ & 125 \\
Total $\mathrm{Zn}$ & $\mathrm{mgkg}^{-1}$ & 49.5 \\
Total $\mathrm{Mn}$ & $\mathrm{mgkg}^{-1}$ & 68 \\
Total Fe & $\mathrm{mgkg}^{-1}$ & 339 \\
Total $\mathrm{Na}$ & $\mathrm{mgkg}^{-1}$ & 592 \\
\hline
\end{tabular}

$\mathrm{pH}$, hydrogen ion concentration; Ar, argon; Co, cobalt; $\mathrm{Cr}$, chromium; $\mathrm{Cu}$, copper; $\mathrm{Hg}$, mercury; Mo, molybdenum; Ni, nickel; Pb, lead; P, phosphorus; K, potassium; Mg, magnesium; Ca, calcium; S, Sulphur; Zn, zinc; Mn, manganese; Fe, iron; and $\mathrm{Na}$, sodium.

Table SA2. Chemical composition of municipal solid waste compost tea stock solution used to prepare the different compost tea concentrations

\begin{tabular}{lll}
\hline Parameters & Unit & Value \\
\hline $\mathrm{pH}$ & & 7.43 \\
Conductivity & $\mathrm{mmhos}$ & 1.8 \\
$\mathrm{Nitrate}$ & $\mathrm{mg} / \mathrm{L}$ & 98.4 \\
$\mathrm{Ca}$ & $\mathrm{mkg}^{-1}$ & 78.09 \\
$\mathrm{~K}$ & $\mathrm{mgkg}^{-1}$ & 162.78 \\
$\mathrm{Mg}$ & $\mathrm{mgkg}^{-1}$ & 14.96 \\
$\mathrm{P}$ & $\mathrm{mgkg}^{-1}$ & 2.00 \\
$\mathrm{~B}$ & $\mathrm{mgkg}^{-1}$ & 0.62 \\
$\mathrm{Cu}$ & $\mathrm{mgkg}^{-1}$ & $\mathrm{ND}$ \\
$\mathrm{Fe}$ & $\mathrm{mgkg}^{-1}$ & 0.10 \\
$\mathrm{Mn}$ & $\mathrm{mgkg}^{-1}$ & 0.15 \\
$\mathrm{Zn}$ & $\mathrm{mgkg}^{-1}$ & $\mathrm{ND}$ \\
\hline
\end{tabular}

$\mathrm{ND}$, not detected; $\mathrm{pH}$, hydrogen ion concentration; $\mathrm{Ca}$, calcium; $\mathrm{K}$, potassium; $\mathrm{Mg}$, magnesium; $\mathrm{P}$, phosphorus; $\mathrm{B}$, boron; $\mathrm{Cu}$, copper; Fe, iron; $\mathrm{Mn}$, manganese; and $\mathrm{Zn}$, zinc.

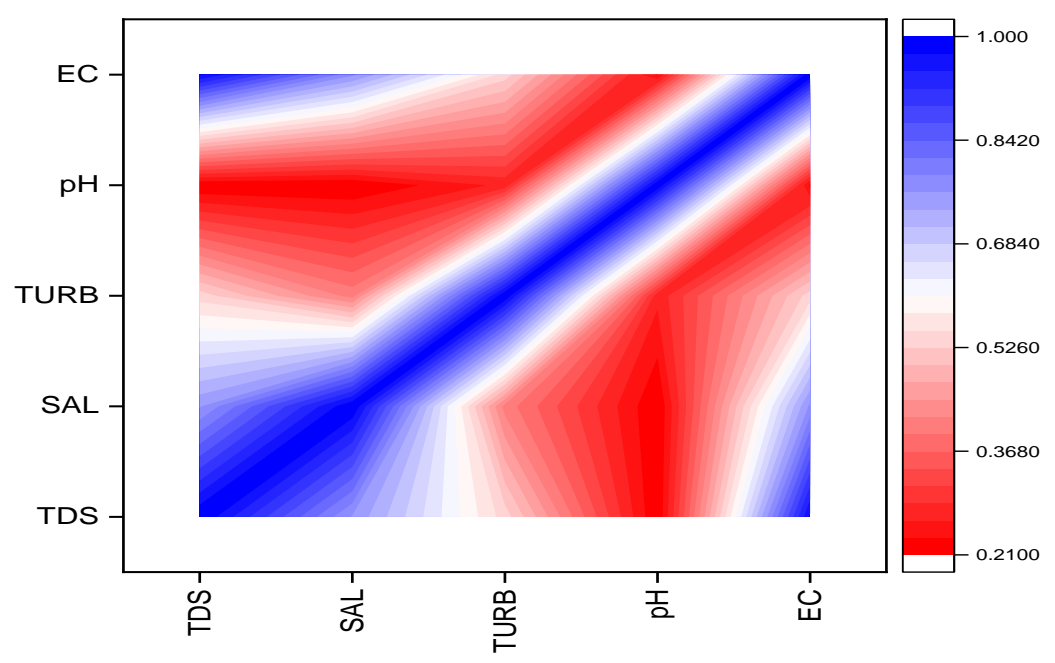

Figure SA1. Pearson's correlation matrix comprising electrical conductivity (EC), hydrogen ion concentration (pH) total dissolved solids (TDS), salinity (SAL) and turbidity (TURB) of municipal solid waste compost tea 


\section{Copyrights}

Copyright for this article is retained by the author(s), with first publication rights granted to the journal.

This is an open-access article distributed under the terms and conditions of the Creative Commons Attribution license (http://creativecommons.org/licenses/by/3.0/). 